\title{
Managing Federal Lands: Replacing the Multiple Use System
}

The federal government manages almost a third of the surface area of the nation ${ }^{1}$ under a management system which tends to favor local users, particularly commercial interests. Recreation and conservation interests are underrepresented in the management process. There are several reasons for this imbalance: Congress has given the executive branch almost no statutory guidance for setting priorities, and has delegated near total discretion in picking among alternative land uses. Within the executive branch, the two agencies responsible for administering most federal lands-the Forest Service and the Bureau of Land Management ${ }^{2}$-have shifted decisionmaking authority to the local level, where local interests predominate. These agencies have been exempted by Congress from many of the procedural requirements which have traditionally insured some degree of formal involvement by the general public in administrative decisions.

The present "multiple use" system should be replaced with one incorporating a "limited use" concept, in which Congress would determine single or dominant purposes for all federally-owned tracts of land. New agencies could be established to administer land designated for each purpose, and could be subjected to the procedural requirements normally applied to administrative agencies. These measures would be designed to insure representation of all interests-the recreationist who lives in an eastern city as well as the logging company located near a western tract-and fulfill Congress' original mandate that federal lands be managed in a way that "will best meet the needs of the American people."3

1. United States Public Land Law Review Comassion, ONe Tuird of the Nation's LAND 19 (1970) [hereinafter cited as PLLRC RElorT].

2. The Forest Service, within the Department of Agriculture administers twenty-five percent of all federal lands. PLLRC REPORT at 22 (chart). The Burcall of Land Management [hereinafter cited and referred to as the BL.MI, an agency in the Department of the Interior, has control of sixty-two percent of all federal holdings. Id. Ifuch of the land it controls is in Alaska. PLLRC REPORT at 327.

3. 16 U.S.C. $\$ 531$ (a) (1970); 43 U.S.C. $\$ 1415(b)$ (1970). The demands made by the American people for use of federal land, particularly for timber and recreation purposes, are growing rapidly. Forest Service figures show that in 1954 timber sales from the national forests amounted to $5,474,000,000$ board fect; in 1964 the figure was $11,141,000$, 000. M. Clawson, The Federal LaNds since 1956, App. Table 3 (1967). Sales vere up another fifteen percent by 1969. M. FroMe, THE Forest SERvice 85 (1971) [hercinafter cited as Frome]. In 1954 there were 40,304,000 visits to Forest Service lands for recrea. tion, and in 1964 there were 133,762,000. M. Clawsox, supra, at App. Table 4. 


\section{The Multiple Use System}

\section{A. The Absence of Statutory Guidance}

The land agencies are directed by statute to manage most federal lands for "multiple use," 4 which in practice means that they have nearly unlimited discretion in the allocation of land to particular uses. The statutory definition of the term "multiple use" is a collection of vacuous platitudes, providing authority for the "judicious use" of land resources, "periodic adjustments in use to conform to changing needs and conditions," and consideration of the "relative value of the various resources" in case of conflict." The Forest Service act lists five contemplated uses of National Forest lands: "outdoor recreation, range, timber, watershed, and wildlife and fish purposes." A special provision states that "the establishment and maintenance of areas of wilderness are consistent with the purposes and provisions" of the act. ${ }^{7}$ None of these possible uses, under either this legislation or the similar BLM act, ${ }^{8}$ is given priority status. ${ }^{8}$

Before passage of its multiple use statute in $1960,{ }^{10}$ the Forest Service only had authority to manage its lands for timber and water resources. ${ }^{11}$ However, the expansion to "multiple" uses merely served to legitimate what the Service had actually been doing for more than thirty years. ${ }^{12}$ Between the wars, the Forest Service came to

4. Both the Forest Service and the BLM are to manage lands for "multiple use." 16 U.S.C. $\$ 529$ (1970); 43 U.S.C. $\$ 1413$ (1970). The Forest Service Act is permancnt; the BLM Act was only temporary and has already expired. See p. 789 infra.

5. The full definition from the Forest Service Act is as follows:

"Multiple use" means: The management of all the various renewable surface re. sources of the national forests so that they are utilized in the combination that will best meet the needs of the American people; making the most judicious use of the land for some or all of these resources or related services over areas large enough to provide sufficient latitude for periodic adjustments in use to conform to changing needs and conditions; that some land will be used for less than all of the resources; and harmonious and coordinated management of the various resources, each with the other, without impairment of the productivity of the land, with consideration being given to the relative values of the various resources, and not necessarily the combination of uses that will give the greatest dollar return or the greatest unit output.

16 U.S.C. $\$ 531$ (a) (1970). The BLM version, referring to "lands" generally, is at 48 U.S.C. $\S 1415(\mathrm{~b})(1970)$.

6. 16 U.S.C. $\$ 528$ (1970).

7. 16 U.S.C. $\$ 529(1970)$.

8. The BLM is afforded a few more contemplated purposes. 43 U.S.C. $\$ 1411$ (a) (1970) lists, in addition to the five Forest Service objectives and wilderness, the following: in. dustrial development, minerals, occupancy, and "preservation of public values that would be lost if the land passed from federal ownership."

9. See, e.g., H.R. REP. No. 1551, 86th Cong., 2d Sess. 3 (1960); 48 C.F.R. $\$ 1725.9 .1$ (1972).

10. Act of June 12, 1960, Pub. L. No. 86.517, 74 Stat. 215, 16 U.S.C. $\$ \$ 528.81$ (1970)

11. 16 U.S.C. $\$ 475$ (1970). This direction dates from 1897 . Act of June 4,1897 , ch. 2 , $\$ 1,30$ Stat. 34 .

12. Most of the Forest Service lands were set aside during the 1890 's, under legislation which permitted the President to close selected unclaimed western lands to homestending 
recognize that various values and uses had to be accommodated with the management of water and timber. It set aside large tracts of undeveloped land to be preserved as wilderness. ${ }^{13}$ It developed roads and campgrounds for automobile tourists. It allowed grazing on the meadows and grasslands under its care, with a permit system later copied by the Grazing Service and the BLM. It preserved wildlife habitats, and leased land out for intensive recreational development. ${ }^{14}$ The multiple use statute in effect ratified these practices.

The BLM administers the remainder of the old vacant lands of the American west. ${ }^{15}$ It was not given any comprehensive statutory guidance for the management of its lands until 1964, when Congress passed a multiple use act patterned after the Forest Service statute. ${ }^{10}$ Although the BLM's act was temporary and was allowed to expire without replacement in $1971,{ }^{17}$ the Bureau continues to manage its lands on a multiple use basis. ${ }^{18}$

Until 1934, there was almost no active management of the BLM

and thereby assure that they would remain under federal control. Act of March 3, 1891, ch. 561, $\$ 24,26$ Stat. 1103, 16 U.S.C. $\$ 471$ (1970). These reserved lands came under control of the Forest Service in 1905 . Act of Feb. 1, 1905, ch. 228, $\$ 1,33$ Stat. 628, 16 U.S.C. $\$ 472$ (1970). After 1911 the federal government purchased lands in the east and added them to the National Forest system. This program was authorized by the Wecks Act, Act of March 1, 1911, ch. 186, $\$ 6,36$ Stat. 962, amended by Act of June 7,1924 , ch. $348, \S 6,43$ Stat. 654 , codified as amended at 16 U.S.C. $\$ \$ 515.19$ (1970). These eastern lands are still treated differently from the reserved public domain lands, particularly with regard to prospecting and mining privileges. See 16 U.S.C. $\S 482$ (1970); 43 C.F.R. $\$ 3811.1$ (1972).

13. Frome, supra note 3 , at 94-96.

14. Hearings on H.R. I0572 Before a Subcomm. of the House Comm. on Agriculture, 86th Cong., 2d Sess. 37-39 (1960).

15. The BLM is the successor of the General Land Office, whose task it was to orersee the disposition of federal land to homesteaders, stockmen, and other private parties. M!. Clawson, The Bureau of Land Management 28 (1970) [hereinafter cited as Clawson]. The Land Office, and the Grazing Service within it, were organized into the BL.M in 1946. 1946 Reorg. Plan No. 3, $\$ 403$, eff. July 16, 1946, 60 Stat. 1100 . See Clissox 38. Land dispositions continued on a large scale through the 1930's. CLAwsos 16-17. By then, the National Forest system had been removed from Land Office jurisdiction and the better lands had passed into private hands. Today the BL.M is left with little more than semidesert, desert, and Alaskan tundra to manage. Clatson 43.

Exceptions to this general rule are the blocks of woodland in the Pacific Northwest known as the $O \&$ \& and Coos Bay Wagon Road lands. A special set of statutory provisions governs BLM management of these lands, barring homesteading and cstablishing a special administrative fund. 43 U.S.C. $\$ \$ 1181$-81f (1970). Concerning the fund, see note 69 infra.

16. Act of Sept. 19, 1964, Pub. L. No. 88-607, 78 Stat. 986, 43 U.S.C. \$S $1411-18$ (1970).

17. The Classification and Multiple Use Act of 1964, 43 U.S.C. \$S 1411-18 (1970), was passed in companion legislation to that which created the Public Land Law Review Commission, infra note 55 . It was regarded as carctaking legislation to keep the BLMI going until the Commission could make its report. The Act was to expire six months after the Commission's report was issued, 43 U.S.C. $\$ 1418$ (1970), and the report came out in the summer of 1970. The Classification and Multiple Use Act duly expired in January of 1971. The BLM now manages some of its land on the authority of the Taylor Grazing Act. There is no single, comprehensive authority for management of the rest.

18. 43 C.F.R. $\$ 1725.1$ (1972). The administration introduced legislation which would have provided permanent multiple use authority for the BLAI, but it died in committce. H.R. 10049, 92d Cong., Ist Sess. (1971). 
lands, since they were all expected to pass into private hands. In that year Congress passed the Taylor Grazing Act, designed to stabilize the use of public domain by the stock raising industry. ${ }^{10}$ Much of the land now controlled by the BLM was organized into "grazing districts" which were to be managed for their forage resources.20 The rest remained in limbo, nominally available for homestending but with few applicants for the privilege. ${ }^{21}$ This land remains under federal control by default. For thirty years it has been clear that it would not be homesteaded, but Congress provided no guidance as to its management before the temporary act of 1964, and none exists today.

\section{B. Agency Land Allocation Decisions}

Under current land agency procedures, the interests of those not located near public lands are strongly disadvantaged in the process of allocating land among competing users. Most other federal administrative agencies provide for at least minimal public comment during the rulemaking process and for the effective representation of aggrieved parties in agency adjudications. The Forest Service and the BLM, however, provide few opportunities for formal public involvement in preparation of their land allocation plans, and they adjudicate individual land use applications and appeals in a manner which seriously hampers intervention by concerned recreation and conservation groups. At the same time, ample opportunity is provided for informal pressure on agency planners and decisionmakers at the local level, since present agency procedures give local officials critical decisionmaking responsibility. Local users have the best opportunity to exert such pressure; those located in other parts of the country, many of them having strong recreational or conservationist concerns, are virtually unrepresented. Among local users, commercial interests appear to have an advantage over others, as a result of their financial and organizational strength.

19. Act of June 28,1934 , ch. 865,48 Stat. 1269,43 U.S.C. $\$ \$ 315 \cdot 15 \mathrm{~g}, 315 \mathrm{~h} \cdot 15 \mathrm{~m}, 815 \mathrm{n}$, 3150-1 (1970). The act established a permit system for forage rights on certain public domain lands designated by the agency. Grazing districts were to be administered by a new Grazing Service within the General Land Office. This was the first statutory sug. gestion that some Land Office lands merited active administration, at least "pending .. f. final disposal" of the land. 43 U.S.C. $\$ 315(1970)$.

20. In 1968 there were almost 160 million acres in grazing districts. Hearings on Grazing Fees on Public Lands Before a Subcomm. of the Senate Comm. on Interior and Insular Affairs, 91st Cong., 1st Sess. 131 (1969).

21. The absence of active management continued with respect to this land. For example, until the 1950's no funds were available for recreational planning or develop. ment. Clawson, supra note 15 , at 23 . 


\section{Planning}

The Forest Service traditionally, and the BLMI increasingly, relies on line officers at the district level to prepare plans for the use of lands under their control. ${ }^{22}$ These district officers are subject to two forms of internal agency supervision: planning guidelines and review of completed plans.

General policy guidelines are issued by the TVashington offices of the agencies. ${ }^{23}$ Regional offices are expected to transmit these guidelines to district personnel, and to add technical advice provided by specialists at the regional level. District officers thus receive a collection of plans prepared by specialists in particular fields, such as timber, watershed, recreation, and range management. ${ }^{24}$ These different plans, each emphasizing development of a particular resource on the same piece of land, are often inconsistent. The district officer must reconcile them, and prepare a unitary plan for his district. ${ }^{25}$

Once a district officer has adopted a plan, he sends it back to the regional office for approval and integration into a regional plan. ${ }^{30}$ This procedure, together with personal inspections by supervisors, is designed to insure that no local officer exceeds his authority and that officers have at least considered alternatives to the plan chosen. In both agencies, the decision of the local officer is respected as the view of a professional particularly well acquainted with the land under his supervision, ${ }^{2 \pi}$ and he is consequently given great latitude in planning. ${ }^{28}$

There is little opportunity for public involvement in reviewing or challenging the decisions of district officers, or of any other officials, in this process. Since matters "relating to ... public property" do not

22. These line officers, occupying the lowest levels in the management hicrarchy of each agency, are designated District Rangers by the Forest Service and District Officers by the BLM. There are over 800 ranger districts in the Forest Scrvice, Frosie, supra note 3 , at 37 , and sixty-three district officers in the BLM, CLAvsox, supra note 15, at 56. The Forest Service Manual notes that the Ranger District organization carries out all management functions with the assistance of staff experts from higher levels. US. Dep'T OF AGriculture, U.S. Forest Service, MANual \$ 1221.71 (1968) [hereinafter cited as Forest SERvice MAANual]. See also Hall, Myth and Reality of Mulliple Use Forestry, 3 NAT. Resources J. 276, 284 (1963).

23. These are known as "directives" and make up a part of the loose-leaf Forest Service and BLMI Manuals.

24. In the BLM, the state-office-level specialists prepare tentative plans for management of one particular resource. CLAwson, supra note 15 , at 55 . In current Forest Service practice teams of specialists from the Forest Supervisor's Office inspect a "planning unit" and draw up a set of alternative plans, generally one which will emphasize each of the major resources. See Forest Service MaNual \$ 2111.7 (1971).

25. ClawsoN, supra note 15, at 55; Forest Service MINNual \$ 2111.8 (1971).

26. See H. KaufMan, The Forest RANGer: A Studi in AdMiNismative Belihson 102 (1960); Clawson, supra note 15, at 59; Forest SERvice Manuat \$ 2111.9 (1971).

27. H. Kaufman, supra note 26, at 83-84; Clawson, supra note 15, at 56.57.

28. Hall, supra note 22, at 284. See also Henning, Natural Resources Administration and the Public Interest, 30 PUв. ADMIN. REv. 134 (1970). 
fall within the rulemaking provisions of the Administrative Procedure Act, ${ }^{29}$ land use plans do not have to be published in the Federal Register for the purpose of eliciting public comment. While plans are often submitted to advisory boards composed of interested users, ${ }^{30}$ these boards have been set up by the agencies ${ }^{31}$ largely as public relations tools, and could be abolished if they tried to interfere with the agencies' work. They exist for the benefit of agency personnel, ${ }^{82}$ who are not required to consult the boards on any subject. ${ }^{33}$

\section{Adjudication}

Land agency adjudications fail to serve as forums for the presentation of opposing user interests because of their limited scope and summary procedures. An adjudication is designed not to review the brond policy decisions expressed in a land use plan, but rather to settle the narrow question of whether a particular land use application is consonant with the plan. The agencies hardly welcome conservation group appeals with respect to grazing permits or timber contracts. By the same token, the Sierra Club and similar organizations lack sufficient personnel and money to intervene in all the local use applications in order to argue for their conception of the public interest.

Even in those rare cases in which a particular commercial application is deemed important enough to warrant legal opposition by recreation or conservation groups, land agency procedures present a formidable barrier. Once again, the Administrative Procedure Act is largely inapplicable, since no record is required and no hearing made manda-

29. 5 U.S.C. $\$ 553$ (1970). Land plans would otherwise fall within the Act's definition of "rule." Were the act applicable, proposed plans would by statute have to be pub. lished in the Federal Register for public comment thirty days before adoption. This exception to the Administrative Procedure Act has been much criticized but not yet deleted. See generally Bonfield, Public Participation in Federal Rulemaking Relating to Public Property, Loans, Grants, Benefits, or Contracts, 118 U. PA. L. REV. 540 (1970).

30. The Forest Service has set up a network of more than 166 advisory bonds to meet with regional, local and national officials and discuss policy matters. Heyman \& Twiss, Environmental Management of the Public Lands, 58 CALiF. L. Rev. 1364,1409 n.176 (1971). The BLM has a similar network. PLLRC REPORT, supra note 1, at 288.

31. An exception is the network of Grazing District Boards, set up by statute in an amendment to the Taylor Grazing Act in 1939. Act of July 14, 1930, ch. 270, 53 Stat. 1002, amending Act of June 28, 1934, ch. 865, 48 Stat. 1269, codified as amended at 48 U.S.C. $\$ 3150-1$ (1970). Each local grazing district has a board composed of one wildlife expert and from five to twelve local ranchers. The intention of the framers of this amendment was to provide the Grazing Service with the assistance of knowledgeable local residents in drawing up the boundaries of the new districts and in allocating permits to use them. In 1950 Congress established similar grazing boards for the Forest Service. Act of Apr. 24, 1950, ch. 97, $\$ 18,64$ Stat. 87, 16 U.S.C. $\$ 580 \mathrm{k}(1970)$. Permit zones and tenure have been stabilized for thirty years now, and the boards carry on as formally established interest groups.

32. See, e.g., FOREST SERVICE MIANUAL \$ 1352.02 (1972). See also id. at $\$ 1352.41$ (1972) (agency officer alone is empowered to call meetings and may terminate them at will).

33. See, e.g., Forest Service MIANUAL \$ 1352.03 (1972). 
tory ${ }^{34}$ at early stages of the process. As a result, land agency adjudications are often summary. ${ }^{35}$

Judicial review of agency adjudication offers little hope for a party or intervenor unsuccessful at the agency level. Under the broad delegations of the multiple use acts, courts are hesitant to overrule land agency decisions. A plaintiff challenging such a decision would have to show abuse of discretion or a total failure to consider "the relative values of the various resources" involved. ${ }^{30}$ No plaintiff has sustained that burden to date. ${ }^{37}$

\section{Commercial Pressure on Agency Decisionmakers}

Users who are not directly involved in local land use applications will thus have few opportunities to influence the allocation of federal lands through formal means of intervention. This situation might be of little concern if land agency officials could be insulated from all

34. The provisions of the Administrative Procedure Act regulating adjudication apply only when a record developed at a public hearing is necessary before decision is reached. 5 U.S.C. $\$ 551$ (1970). In the land management statutes, only the Taylor Act imposes such a requirement. 43 U.S.C. $\$ 315(1970)$. Thus land use decisions outside of the creation of a grazing district need not be reviewed by an independent examiner, after oral presentation of evidence and cross-examination, as the Administrative Procedure Act would normally require.

35. Applications for particular land uses are generally written and submitted to a deciding officer in both the BLM and the Forest Service. If an application to the Forest Service is challenged the officer may at his discretion consider the written arguments of the challenger. In BLM challenges, if one potential user is challenging the title or interest of some other person in a tract of federal land, the procecding is called a "contest" and a hearing is granted. 43 C.F.R. $\$ 4.450-1$ (1972). In cases which do not involve the titles or interests of two private parties, the adjudication is called a "protest" and the agency may allow or refuse a hearing at its discretion. 43 C.F.R. $\$ 4.450 .2$ (1972).

The initial decision may be appealed to intermediate levels of the agency hicrarchy and to Washington. 36 C.F.R. $\$ 211.21$ (1972); 43 C.F.R. $\$ 4.410$ (1972). The appeal is made difficult by the fact that the ultimate decision may turn on issues not argued below. McCarty, A View of the Decision Making Process Thithin the Department of the Interior, 19 ADMIN. L. REv. 147, 175-78 (1967). Appeals within the Forest Service are made on the basis of the original papers and statements of the deciding officer and the applicant. 36 C.F.R. $\$ 211.21$ (1972). Third parties such as conservation groups are generally able to prosecute appeals, though they are not formally entitled to do so by the agency regulations. In the Forest Service, anyone "adversely affected" may appeal a decision if the decision is "appealable." The only decision which is not appealable is rejection of a bid. 36 C.F.R. $\$ 211.21$ (a) (1972). Review in the BL.M is limited to "partics to the case." 43 C.F.R. $\$ 4.410$ (1972). On the difficulty of interiening in a BL.I ad. judication, see Note, Conservation and the Public Lands: Administrative and Judicial Remedies Relating to the Use and Disposition of the Public Lands Administered by the Department of the Interior, 68 MICH. L. REv. 1200, 1213-18 (1970).

36. The Multiple Use Acts require such consideration. 16 U.S.C. $\$ 531(a)$ (1970); 43 U.S.C. $\$ 1415(\mathrm{~b})(1970)$.

37. See, e.g., Sierra Club v. Hardin, 325 F. Supp. 99, 122.23 (D. Alas. 1971) (suit to enjoin performance of fifty-year contract between Forest Service and lumber company for lumbering of the Tongass National Forest; Sierra Club had failed to exhaust administrative remedies, but lost on the merits as well); Dorothy Thomas Foundation Inc. $v$. Hardin, 317 F. Supp. 1072, 1075 (W.D.N.C. 1970) (suit to enjoin cutting of National Forest land contiguous to private summer camp; plaintilts failed to produce "one scintilla of evidence" of abuse of discretion which would justify preliminary injunction). 
user pressure, so that they could manage federal lands solely on the basis of their expert judgment and close knowledge of their districts' problems. However, even the most highly trained and well-intentioned district officer is likely to be influenced, however subtly, by the local users with whom he must constantly deal.

This influence takes three principal forms. First, the line officer's friends and neighbors are the same local people who make demands on the resources under his control. There is understandable social pressure to conform to their wishes. ${ }^{38}$ Second, these same local users are likely to sit on the advisory boards with which the line officer deals. ${ }^{\text {a }}$ Even without real authority, such boards can assume the role of organized lobbies for the common interests of their members. Finally, the agency adjudication process is used heavily by local persons to challenge decisions about the use of particular lands. The decisions of agency officials at both the local and regional levels may reflect the desire to placate such interests in order to minimize time-consuming appeals. ${ }^{40}$

Recreational users living far from federal lands cannot successfully compete with these local users in exerting informal pressures at the local level. Non-local commercial interests, in addition to recrention. ists, may be disadvantaged in their competition with local commercial users. Such commercial interests, however, are more likely to have the financial and organizational strength necessary to represent their views in the local decisionmaking process, and compensate at least partially for their geographical separation. Non-local recreational users and conservationists may be almost totally unrepresented in the local process,

38. H. KAUFMaN, supra note 26, at 75-77. (1970).

39. See Heyman, Land Planning on Public Lands, 6 LAND \& WATER L. REv. 887, 109

40. Professor Kaufman makes the following observation about Forest Service ad. judications:

Every Ranger and former Ranger interviewed in the course of this study has been involved in appeals cases of some kind. It is accepted as one of the hardships of doing public business in a democratic government and is not ordinarily treated as a discredit, even if a field officer is eventually overruled. Yet it is a bother, at best-a distraction from the more "productive" labors of the members of the Forest Scrvice, a cause of additional paperwork, a generator of inspections and inquiries from higher levels. And it is certainly true that, at worst, a Ranger whose constituency is constantly restive and rebelliots is likely to stimulate some doubts about his ju. diciousness and skill. So Rangers prefer to avoid them if they can, and are confronted with a delicate choice between the annoyance and risk of continuous skirmish. ing with local interests on the one hand, and conceding away elements of the Forest Service program (perhaps to save the remainder) on the other.

H. KaUfMan, supra note 26 , at $78-79$.

As an indication of the kind of adjudicative pressure under which the agencies now operate, the BLM reported that it had 120,082 adjudications open in 1971, and closcd 74,882 of them. United States Department of the INTERIor, BUREau of LANd MANaGeMent, Public Land Statistics 1971 , at 146. 
and they ordinarily lack the funds and personnel to appeal through the agency's adjudicatory process.

Similarly, at the national level, commercial users have an advantage over recreation advocates, for two reasons. First, persons and firms interested in obtaining exploitation rights on public lands are much fewer in number than the potential recreational users. This alone makes the cost of organizing a collective pressure group much smaller for the commercial interests than for recreationists. ${ }^{11}$ Second, conservationists labor under the "free rider" problem; their members' incentives are undercut by the fact that, even when they win favorable planning decisions, they do not gain exclusive use of the benefits of their victory. ${ }^{42}$

\section{Limited Use Alternatives}

To the extent that the imbalance of influence is aggravated by the ambiguity of multiple use directives, the solution might be for Congress to enact statutes limiting the uses of particular tracts of federal

41. See M. Orson, The Logic of Collective Action 46-47 (1965). See also id. at 48, discussing reasons why larger groups fail to achieve their common interests as cffectively as smaller groups.

42. A free rider is one who benefits from a public good without paying for it. See J. Buchanan, The Deacand and Suprey of Public Goods 87 (1968). The free rider problem makes it difficult for recreational and conservation groups to raise the funds necessary to protect their interests.

That commercial lobbying is effective at the national level can be seen from two recent controversies. In 1966, a joint study by the Forest Service and the BLM estab. lished that grazing fees for that year should have been, by fair market value, $\$ 1.23$ per animal-unit-month (a figure roughly equivalent to the amount of fodder needed to feed a mature cow for a month). The fee actually charged in the BLNI was 33\&. Both agencies adopted schemes to bring grazing fees up to market value over a ten year period. Congress refused to prohibit these proposed increases, and a court challenge to them failed. See Pankey Land \& Cattle Co. v. Hardin, 427 F2d 43, 45 (10th Cir. 1970). Despitc congressional acquiescence in the change, Interior Secretary Hickel decided that there would be no fee increases on the BLA grazing lands. See Ciswson, supra note 15, at 175-77.

In 1969, several congressmen supported a timber-lobby bill that would have increased allowable cuts and returned some of the profits from timber sales into a special fund to be used for construction of access roads to open up more timber for cutting. S. 1832, 91st Cong., Ist Sess. (1969). Aroused conservationists blocked passage of the bill. Within a year, President Nixon ordered the Forest Service to increase allowable cuts and use more federal funds to construct access roads. See Frosie, supra note 3, at 167-73.

Recent congressional hearings uncovered commercial abuse of public lands which is at least partly the result of the imbalance of influence between developers and conservationists. Hearings on Clear-Cutting Practices on National Timberlands Before a Sub. comm. of the Senate Comm. on Interior and Insular Affairs, 92d Cong., lst Sess. (1971). Senator Gale MicGee of Wyoming stated at the hearings that there would be litule log: ging in his state if the Forest Service did not permit destructive practices; he labelled the Service the "nursemaid" of the timber industry. Id. at 7 . The hearings also brought out evidence of widespread overuse of National Forest grazing lands; almost four-fifths of suitable grazing land under the Forest Service was in either "fair" or "poor" condition in 1969. Id. at 297-301. The witness who gave this information blamed rancher organizations, including advisory boards, for pressuring the agency into permitting such overuse. $I d$. 
land. Such "limited use" management would entail the designation of a particular favored use for each tract of land, and could take two distinct forms: other uses could be permitted to the extent that they did not interfere with the favored use, or other uses could be barred from the land altogether. These two alternatives will be referred to, respectively, as "dominant" and "single" use management.

Limited use management would not be novel in and of itself. It is already practiced, however imperfectly, in several of the smaller federal land agencies and management systems. Furthermore, a special commission established by Congress to study current laws relating to use of public lands has suggested that most of the land now under the multiple use statutes be managed according to the dominant use concept. The example of the smaller agencies and the proposals of the commission, with appropriate revision, could provide a framework for restructuring the system of federal land management to insure adequate consideration of all competing interests in federal lands.

\section{A. Existing Limited Use Systems}

The two primary land management agencies, outside of the Forest Service and the BLM, are the National Park Service ${ }^{48}$ and the United States Fish and Wildlife Service.44 Commercial exploitation is almost entirely banned in the National Parks, and is permitted on refuges administered by the Fish and Wildlife Service only when compatible with wildlife protection.

The Park Service is authorized to manage park and monument land in its natural state as "pleasuring-ground" for the people of the nation. ${ }^{45}$ Each park is created by special legislation which defines the uses to which the land may be put, and the Park Service is bound by these special acts. While there are variations among park statutes, ${ }^{40}$ all speak of preserving the land as parks for public enjoyment.

43. The Park Service was established in 1916. Its organizing statute is codified at 10 U.S.C. § I (1970).

44. The Fish and Wildlife Service was established by 16 U.S.C. $\$ 742 \mathrm{~b}(\mathrm{~d})(2)(1970)$, partly to oversee the wildlife refuges created by 16 U.S.C. $\$ 668 \mathrm{dd}(1970)$. The Park Service and the Fish and Wildlife Service together manage over fifty million acres of land. In addition to the 49.9 million listed by the PLLRC, PLLRC REPoRT, supra note 1, at 22 (chart), the Park Service manages several million acres of military cemeteries, national seashores and recreation areas, and other small units. W. EverhiarT, Tile NAtional PARK SERVICE 252-60 (1972).

45. The term is taken from Act of Mar. 1, 1872, ch. 24, \$1, 17 Stat. 32,16 U.S.C. \$ 21 (1970), which established Yellowstone as the first National Park. Preservation of the parks in their natural state is mandatory because they are to be kept "unimpaircd for the enjoyment of future generations." 16 U.S.C. $\$ 1$ (1970).

46. For example, the statute organizing Mount McKinley National Park allows su. pervised prospecting and mining in the park. 16 U.S.C. $\$ \S 350-350 \mathrm{a}$ (1970). Mining is banned in the other parks. W. EverharT, supra note 44 , at 49 . 
Although national parks are devoted to the single "use" of recreationists, the agency must nonetheless reconcile the conflicting demands of different interests within that group-car tourists and backpackers, for example. Still, the most antagonistic potential user, the commercial developer, has been excluded from the parks by statute. ${ }^{47}$ His lobbying power cannot subvert the law's clear direction.

The Fish and Wildlife Service administers National Wildlife Refuges, which were established to protect the habitat of native fish and wildlife, particularly rare and endangered species. ${ }^{18}$ No use conflicting with that aim is permitted on wildlife refuges. ${ }^{* 0}$ Commercial activity is sanctioned only to the extent that it does not interfere with wildlife, and visitors are strictly regulated. ${ }^{50}$ As a result of this relatively clear statutory direction, the wildlife policies of the Fish and Wildlife Service are rarely threatened by commercial interests.

Overlapping all of the federal land agencies is the National Wilderness Preservation System, established in 1964 after years of congressional stalemate.51 The wilderness system is currently the purest of established single use systems, in that no development whatever is permitted on designated lands. Areas placed in the wilderness system are to be preserved, according to Congress' statutory command, "untrammelled by man," retaining their "primeval character and influence without permanent improvement or human habitation." 52

47. The Park Service is entitled to permit grazing in the National Parks, 16 U.S.C. $\S 1$ (1970), but generally no longer does so. U.S. DepartaIENT OF THE INTERIor, NationaL Park Service, Compilation of the administrative Policies for the National Parkis and the National Monuments of Scientific Significance (Natural Area Catecorr) 58 (rev. ed. 1970). But see Shanks, Hansen Country, N.Y. Times, Nov. 27, 1972, at 35, col. 2. describing the grazing privileges of Senator Clifford Hansen in Grand Teton National Park.

The National Park Service administers many lands other than national parks, and so cannot be considered a single use agency. It has been proposed that the agency be split into two parts, one to manage the natural areas and the other the historic parks. N.Y. Times, Sept. 17, 1972, at 1, col. 5.

48. 16 U.S.C. $\$ 668 \mathrm{dd}(1970)$.

49. 16 U.S.C. $\$ 668 \mathrm{dd}(\mathrm{d})(1)(1970)$.

50. Visitors to wildlife refuges may not harm or destroy animals or vegetation, 50 C.F.R. $\$ 26.8$ (1972), or make excessive noise, 50 C.F.R. $\$ 26.20$ (1972). They must stay on roads and paths administered for public use; they may not wander into the backcountry of the refuges unless they have a permit or are accompanied by agency personnel. 50 C.F.R. $\$ \S 28.1(\mathrm{~b}), 28.3$ (1972).

51. The Wilderness Act, first proposed in 1956, was not passed until 1964 and then only in a reduced version. Some of the bills introduced in 1957 vould have included almost sixty million acres in the wilderness system. For examples of such bills, sce, e.g., S.1176 and H.R. 500, 85th Cong., lst Sess. (1957). As finally passed, the act included only nine million acres with provision for adding more. H.R. REP. No. 1538, 88th Cong., 2d Sess. 9-10 (1964). The legislation covering the establishment and expansion of the wilderness system is codified at 16 U.S.C. $\$ \$ 1131-36(1970)$. Wilderness lands are not currently placed under the control of a separate agency; the agency with prior control over newly designated wilderness continues to administer it, but in conformity with the Wilderness Act.

52. 16 U.S.C. $\$ 1131$ (c) (1970). Hence, no roads may be built, no campgrounds may be developed, no timber may be cut, and no buildings may be constructed on designated wilderness lands. 
Further transfers of public land into any of these systems ${ }^{53}$ would protect some land from commercial pressures now threatening the multiple use agencies. More importantly, these systems can serve as models for narrowing the discretion of administrators by centralizing the land allocation decision. ${ }^{54}$

\section{B. The Public Land Law Review Commission Recommendations}

The final report of the Public Land Law Review Commission, ${ }^{\text {to }}$ is. sued in July of 1970, criticized the multiple use statutes of the Forest Service and BLM for failing "to specify or provide standards for determining priorities of use or guidelines for resolving conflict." 60 The Commission's proposed solution was to authorize zoning of lands for dominant use. ${ }^{57}$ Only if a particular tract of land had no clearly identifiable "highest" use would it remain unzoned and managed for multiple uses. ${ }^{58}$ The task of classifying lands for dominant use would be carried out by the existing agencies rather than by Congress. ${ }^{50}$ District officers, in consultation with new statutorily-created advisory

53. Both the Wilderness and National Park Systems are still growing. Congress has directed that the Park and Forest Services review certain of their lands to determine which should be added by Congress to the Wilderness System. 16 U.S.C. $\$ 1182(\mathrm{~b}) \cdot(\mathrm{c})$ (1970). The reviews are to be completed by 1974. To date Congress has added allte over a million acres to the Wilderness System, all but 200,000 of them from Forcst Service primitive areas. These additions are effected by discrete acts of Congress, not codified. Wilderness area legislation, through the 91st Congress, from which the above figures were drawn, will be found in the following Acts: Act of Mar. 21, 1968, Pub. L. No. 90-271, 82 Stat. 51; Act of May 24, 1968, Pub. L. No. 90-818, 82 Stat. 181; Act of Sept. 28, 1968, Pub. L. No. 90-532, 82 Stat. 883 (includes 3700 acres of Department of the Interior land); Act of Oct. 2, 1968, Pub. L. No. 90-544, \$\$ 601-04, 82 Stat. 926; Act of Oct. 2, 1968, Pub. L. No. 90-548, 82 Stat. 936; Act of Aug. 18, 1969, Pub. L. No. 91.58, 83 Stat. 101; Act of Oct. 10, 1969, Pub. L. No. 91-82, 83 Stat. 131; Act of Oct. 29, 1970, Pub. L. No. 91-504, 84 Stat. 1104 (includes about 190,000 acres of Department of In. terior land).

In addition, Congress is free to consider wilderness area proposals which do not have agency blessing. No such proposals were passed until the 92d Congress met; it cnacted two. Act of Aug. 20, 1972, Pub. L. No. 92-395, 86 Stat. 578 (new area in Montana); Act of Oct. 21, 1972, Pub. L. No. 92-521, 86 Stat. 1026 (addition to existing area in Oregon).

Eight new national parks have been established in the last ten years. Six are listed by W. Everhart, supra note 44, at 252. Arches National Park was created by Act of Nov. 12, 1971, Pub. L. No. 92-155, 85 Stat. 422, and Capitol Reef National Park by Act of Dec. 18, 1971, Pub. L. No. 92-207, 85 Stat. 739, after Everhart's work was published.

54. Wildlife refuges and national monuments may be created by executive order without an act of Congress. 16 U.S.C. $\$ 668 \mathrm{dd}(\mathrm{c})(1970) ; 16$ U.S.C. $\$ 481(1970)$. Each is administered under a dominant use system. 16 U.S.C. $\$ 668 \mathrm{dd}(\mathrm{d})$ (1) (1970); 16 U.S.C. $\S 4504-2(a)$ and $\S 4504-2(b)$ (1970). Parks are created by act of Congress only and are managed under a single use system. See p. 796 supra.

55. The Public Land Law Review Commission was established in 1964 to engage in a comprehensive review of laws relating to public lands. 43 U.S.C. $\$ 1412$ (1970).

56. PLLRC REPORT, stipra note 1 , at 49 .

57. Id. at 51 .

58. Id. Note that since the land most attractive for timber cutting might also be the most attractive for recreation, the "highest use" of such land would be very difficult to determine.

59. Id. 
boards, ${ }^{80}$ would determine the dominant use of a particular tract of land.

Like the present multiple use system, the Commission's proposed system would depend on the expertise of local land agency managers, who would be subject to exactly the same pressures that beset current agency planning. The advisory board system suggested by the Commission would formalize rather than reduce the bias in favor of local users, since the boards would be composed of local persons representing local interests ${ }^{01}$ and planners would be required to confer with them at all stages of the planning process. ${ }^{02}$

\section{Limited Use Administration of All Federal Lands}

The major flaw in the Commission's proposed system-its susceptibility to local pressure-would be cured if Congress allocated lands to a single or dominant use.

The limited use concept, combined with a shift of decisionmaking power to a national public forum, would provide opportunities for representation of all interests in the land allocation decision. Further, once the dominant uses were fixed, there would be little to gain from pressuring a local administrator, for he would be bound by congressional directive.

In attempting to establish a limited use system on a national scale, Congress would be faced with two tasks. It would have to revise the directive legislation for management agencies, so that each would have a clearly defined end to which to apply its expertise; and it would have to give each agency appropriate land to manage. The former task could be completed by Congress itself; for the latter, professional assistance would be required.

\section{A. Proposed Limited Use Agencies}

Congress could replace all of the existing federal land management agencies with three new ones, responsible respectively for recreation, timber and grazing. The new recreation agency would assume authori-

60. Id. at 60 .

61. The PLLRC states that the local advisory boards "will be comprised of people in the region or locality for which the land use plans are being developed and will represent all of the principal interests affected by the decision flowing from the planning process." Id. at 60 . Agency personnel recognize that advisory boards represent local more than national interests. Clavson, supra note 15, at 149-51; W. Everuinsr, supra note 44, at 91 .

62. PLLRC REPORT, supra note 1, at 60. 
ty for the interests now served by the Park Service, the wildlife refuges, and the wilderness system. The timber agency would have control of all fertile woodlands under federal control except those placed in the recreation system, and the grazing agency would have all range land with the same exception. Hence, the timber and grazing agencies could each concentrate on maximizing production of renewable resources.03

Recreational lands would be managed under a modified single use system. Although both wilderness and recreation lands would be managed by a single agency, they would be strictly segregated by statute. Wildlife preservation would be given equal priority with the favored use in each of these segregated systems. Commercial use would be entirely barred from all of the agency's lands.

The timber and grazing agencies, however, would be administered under dominant use guidelines, so that recreation or any other use compatible with the priority commercial use would be permitted. This asymmetrical treatment of commercial and recreational lands is justified for two reasons. First, while heavy commercial use is incompatible with wilderness preservation and some recreational uses, other recreational uses are not necessarily incompatible with commercial use. Therefore, although commercial users should be banned from lands in the recreation system, there is no reason to bar recreationists completely from commercial lands. Second, dominant use administration allows some agency discretion, and would result in the same imbalance as exists in the present system if applied to the new recreational system.

In setting up these new agencies, Congress could adopt an additional procedural reform: all three of the new agencies could be made subject to the provisions of the Administrative Procedure Act. ${ }^{04}$ Proposed land use plans could then be subjected to public comment after publication in the Federal Register, and the review process could provide a forum for discussion of agency plans within the narrowed

63. Commercial lands should continue to be administered on the principle of "sustained yield" written into present legislation. 16 U.S.C. $\$ 531(\mathrm{~b})$ (1970) defincs "sustained yield" for the Forest Service as "the achievement and maintenance of a high-lcvel an. nual or regular periodic output of the various renewable resources of the national forests without impairment of the productivity of the land." See also 48 U.S.C. $\$ 1415$ (c) (1970) for the similar BLM definition.

Commercial lands would not be managed for the environmental values of clean air and pure water, but their managers should be required to respect the National Environ. mental Policy Act, 42 U.S.C. $\$ \$ 4321-47$ (1970). Section 102(2)(c) of the act, 12 U.S.C. $\$$ $4332(2)$ (c) (1970), requires agency personnel to draw up evaluations of the environmental impact of proposed actions.

All lands should be managed to protect water resources; there would be no need for a special watershed agency.

64. 5 U.S.C. \$ 551 et seq. (1970). See pp. 791.93 supra. See also llLRC RErokr, supra note 1 , at 252 , for the commission's opinions on applicability of the Adminis. trative Procedure Act. 
authorizations. Adjudication procedures could also be reformed to require that contested applications be based on a record developed at public hearings. Administrative Procedure Act hearing guidelines would then apply. ${ }^{65}$

\section{B. Allocation of Lands}

In allocating land tracts among alternative uses Congress would need professional advice and expertise. It might be tempted to rely on existing personnel. Present officials, however, have a penchant for empire building, and are more likely to fight for expanded domains than to fairly articulate and choose among the interests involved. ${ }^{\circ}$ The officials of the new agency would probably not behave differently. Thus, an alternative source of expertise, directly responsible to Congress, should be found.

To obtain such expertise, Congress could establish a special commission. Such a body could be assigned the task of proposing a land allocation plan, dividing every tract of land presently under federal control among the new agencies. The Commission's membership could be mandated by statute, with representation for industry representatives, conservationists, and some agency specialists. Its plan, however, would be purely advisory. Congressional approval would be required, along with the normal process of committee consideration, hearings, debate, and recorded vote. Although the Commission would cease to exist following presentation of the plan, ${ }^{07}$ Congress might later revise the allocations initially approved, in response to changing national needs.

65. These guidelines are set out in 5 U.S.C. $\$ \$ 556-57$ (1970). They include an independent trial examiner and opportunity for cross-examination. See note 34 supra.

66. In the North Cascades Park controversy, for example, the Park Service scemed quite content to take land away from the Forest Service, and the Forest Service correspondingly loath to give it up. Only pressure from the cabinet level brought the agencies to create a compromise plan. W. EvERHART, supra note 44, at 189.90. Also, both of the agencies have been slow in review of backcountry areas for possible inclusion in the Wilderness System. The Forest Service still had two and a third million acres of primitive areas to review as of 1972 . Hearings on $S .2453$ and Relaled W'ildermess Bills Before a Subcomm. of the Senate Comm. on Interior and Insular Affairs, 92d Cong., 2d Sess. 89 (1972). In 1964 when reviews began there were five and $a$ half million acres of land in "primitive area" status. Frome, supra note 3 , at 99 . Thus, in the first cight years of the ten year review program, the Forest Service completed slightly more than half of its assigned task. Only 200,000 acres of Park and Refuge land have been added to the Wilderness System, see note 53 supra, which suggests that the Department of the Interior is even farther behind in reviewing its lands.

67. The Public Land Law Review Commission was established on such a format. 43 U.S.C. \$ 1415 (1970). However, membership was mainly from the congressional land committees dominated by westerners. The allocation commission suggested here vould need a more balanced membership. 


\section{Advantages of Such a System}

Shifting land use decisions to the national level, and requiring a single comprehensive review, would enable full representation of all users and interests regardless of their location. At the national level, anyone interested in a particular tract would be informed of the government's proposed use for it; all users could exert influence on Congress as the decisionmaking body. Land use determinations would be reached only after consideration of their views. Commercial users might continue to enjoy an advantage at this level, but conservation and recreation interests would be better able to muster the financial and organizational resources required to exert influence.

Shifting the responsibility for land use decisions from the execu. tive branch to Congress would make the process more visible to the public and more sensitive to individual voters' preferences. Special interests may still lobby before Congress, but Congressmen are at least required to record their votes formally, and justify them to constituents every two years. The Commission, and the congressional committees considering its proposals, would be expected to hold public hearings with opportunities to testify open to all interests. The executive agencies, by contrast, are far less directly responsible to an electorate for their land use decisions. They answer to the President, who runs for reelection only once, and whose campaign is such that performance of his land use agencies is hardly likely to be raised to a level comparable with other matters of domestic and foreign policy. Thus, the national legislature, by virtue of its representative character, is the proper forum for these decisions. ${ }^{68}$

This system of limited use management would have additional advantages. For example, it would facilitate planning for the responsible development of the commercial resources of federal lands. Timber lands could be operated as model tree farms, on the principle of sustained yield. ${ }^{60}$ This principle is presently undercut by the knowledge

68. The defeat of Representative Aspinall in a primary election, the passage of the New York environmental bond issue and the California Coastline referendum, and defeat of the Colorado Olympics suggest that clearcut environmental issues attract voter interest and support. Conservation groups apparently are able to overcome commercial interests' advantages through the electoral process.

69. For definition of sustained yield, see note 63 supra. The tree farm concept im. plies some degree of reinvestment of profits in the production of new timber. Such reinvestment has been practiced with great success by the BLM in managing its timber holdings in Oregon and California. See Hearings on Problems in Lumber Pricing and Production Before a Subcomm. of the Senate Comm. on Banking and Currency, 91st Cong., lst Sess. 614.15 (1969). Automatic reinvestment is provided by 43 U.S.C. $\$ 1181$ (c) (1970). The Forest Service has areas which would return profits on investment, though perhaps not as much as the $O$ \& $C$ lands under the BLM. Lumber Pricing Hearings, supra, at 602 . 
that virgin lands may be opened to exploitation. ${ }^{70}$ Once the available sources of public timber were delineated, the cut-and-run mentality could be restrained. Lumbermen, knowing that only an act of Congress could open up more land to timber interests, would be more receptive to limited cuts and crop rotation plans designed to conserve the timber resource. Similarly, ranchers would be more receptive to conservative grazing practices if their rights and duties regarding public grazing land were clarified by statute. ${ }^{11}$

In general, planning for the use and preservation of recreational areas would be more accessible to public scrutiny. Not only would the Administrative Procedure Act require publication of proposed land use plans, but the large size of the tracts allocated by Congress would reduce the number of plans with which interested groups must deal. ${ }^{22}$ Deviations from statutory guidelines and comments on the wisdom of proposed actions thus could be more easily brought to the attention of administrators before recreation plans became final.

Resort to adjudication would be much less frequent under the new system. The inefficiencies of using the cumbersome, case-by-case adjudicative process for policymaking would disappear once policy was established by Congress. Adjudication would become a process of testing an administrator's actions against congressional directives, as it ought to be. Since there would be manageable directives from Congress greatly narrowing the range of discretion, appeals within the agency and to the courts could provide meaningful control.

70. The lands that have opened up in the past twenty-five years have included a good many marginal sites that should never have been logged. Clearculting Hearings, supra note 42, at 837, 839; Hearings on S. 1832 Before a Subcomm. of the Senate Comm. on Agriculture and Forestry, 91st Cong., lst Sess. 76 (1969). Sustained yicld is impossible on these sites. The prospect of new lands becoming available undermines the incentive to use lands currently available cautiously in order to insure a future supply of lumber.

71. Although the Taylor Grazing Act curbed the worst abuses of the grazing privilege on federal lands, there is still serious overuse of the forage resource. Part of the reason for this is that public grazing fees are very low relative to the market value of the grazing rights. See Grazing Fee Hearings, supra note 20, at 115 -16 (1969). See also note 42 supra on the grazing fee controversy. There is an incentive for ranchers to overuse the Iands simply because use rights are inexpensive, and the ranchers can bring pressure on local administrators to permit overuse. If market fees were required by statute, the fees could be kept at market levels through the Administrative Procedure Act rulemaking process.

72. The Park Service, by agency practice and not by statutory command, holds hearings on proposed master plans and changes in them. Since the hearings are held in the vicinity of the park, public input at the hearing is probably biased in favor of local interests. W. EVERHART, supra note 44, at 91 . There are, however, only thirty-eight national parks, id. at 252 and see note $\mathbf{5 3}$ supra; some of them are relativcly insignificant units like Platt and Hot Springs National Parks, which encompass only 4500 acres between them. Id. at 252. Conservationists can keep much better track of the proposed master plans than they can of the eight hundred or so unpublished ranger district plans in the Forest Service, and can comment in writing after the hearings cten if they cannot attend them. This advantage would be carried over to the new system if recreational units were kept in large tracts. 
Finally, statutory allocation of land would reduce the substantial time and energy now spent by users and managers in lobbying, adjudicating, and commenting on plans.

\section{Costs of a Limited Use System}

If the present system allocates land to commercial uses which a congressional allocation would shift to the recreation systems, the national economy would lose the current production of some commercially valuable lands. However, the lands could always be moved back into one of the commercial systems in the future, so they would retain a potential commercial value. Moreover, the present loss rould be moderated by two factors: first, the timber land allocated to recreation would most likely be the high altitude marginal lands which hold natural stands of timber but are not suitable for tree farming; second, with adequate funding both timber and range lands could be managed more efficiently than they are now, and increased production on intensely-managed lands could make up for the lost production of designated recreation lands. ${ }^{73}$

Mining would not fit neatly into a limited use system, since minerals are not renewable and cannot be managed. If mining were banned on all recreational lands, as it should be in order to keep the lands fit for park and wilderness use, there would undoubtedly be a loss of resources available for current development. ${ }^{74}$ It might be possible for the Geological Survey to prepare an inventory of mineral resources on recreational lands ${ }^{75}$ which could be exploited with congressional authorization in an emergency, but private prospecting and mining would cease.

Closing some public lands to commercial users would undoubtedly cause hardship to particular parties, primarily in the form of increased transportation costs to loggers and ranchers. Over time, the additional cost of transport might force relocation of sawmills and perhaps

73. See note 65 supra on the effects of intensive management of BLM timber lands. Earmarked funds for grazing improvements could provide similar increased returns and charging market value fees should maintain earmarked funds at a high level.

74. Almost all federal land except the national park system is currently open to mining. Lands subject to the General Mining Law of 1872, 30 U.S.C. $\$ \$ 22.38$ (1970), may pass in fee to the prospector who finds minerals on them; other lands and fucl rescrves are subject to a leasing system. See generally Edwards, The 1969 View of the 1872 Latw: Current Proposals to Modernize the General Mining Laws, 15 Rocky MTN. Minekus L. INST. 139 (1969) for an industry explanation of the mining laws and reform proposals.

Prospecting on Wilderness System lands will be banned after December 91 , 1989, but claims located before that date may be exploited. 16 U.S.C. $\S 1133(d)(3)(1970)$.

75. Such a survey is contemplated for wilderness areas. 16 U.S.C. $\$ 1199(\mathrm{~d})(2)(1970)$. 
might lower property values of ranches in given locations. ${ }^{70}$ Consideration should be given to government compensation for some of these losses. ${ }^{77}$

Insofar as flexibility enhances the efficiency of land use management, there would be some economic loss merely as a result of the inflexibility of the new system. But some decreased flexibility seems an inevitable concomitant of the better representation of all interests and improved planning possible through fixed land allocations.

\section{Conclusion}

The present administrative structures of the Bureau of Land Management and the Forest Service do not respond adequately to the full range of user interests. A system of limited use agencies administering centrally-allocated lands could provide a framework for more responsible management of both commercial and recreational lands. Congressional allocation of land to various uses would result in better representation of interests now disfavored, particularly those of recreationists geographically distant from the lands they wish to use. The responsibility for reform rests with Congress.

76. Ranchers would suffer additional hardship if market value were charged for grazing privileges, since many paid inflated prices for base ranches to -which low-cost permits were traditionally given. See Grazing Fee Hearings, supra note 20, at 116-18, 141-42.

77. Held, Whose Public Lands?, 7 Nat. Resources J. 153 (1967) suggests a public policy of relocation and compensation when land is needed to satisfy national demands for recreation and other amenities. 